\title{
Enhancement of Quality and Storability as Well as Rots Reduction of Jerusalem Artichoke Tuber by Co-application of Essential Oils and Temperature
}

\author{
Aml A. El-Awady", K.M. Ghoneem ${ }^{* *}$ and Wesam I.A. Saber ${ }^{* * *}$ \\ *Vegetable Research Department, Horticulture Research \\ Institute ${ }^{* *}$ Seed Pathology Research Department, Plant \\ Pathology Research Institute and ${ }^{* * *}$ Microbial Activity Unit, \\ Microbiology Department, Soils, Water and Environment \\ Research Institute, Agricultural Research Centre, Cairo, Egypt.
}

\begin{abstract}
GEQUENTIAL storage experiment was carried out at Mansoura OHort. Res. Sta., Agric. Res. Center, Egypt, during 2012, 2013 and 2014 seasons. The aim was to increase shelf life, nutritive value, quality and storability of Jerusalem artichoke (JA) fresh tubers, as well as protecting the tubers from the pathogenic fungi, Sclerotium rolfesii, Sclerotinia sclerotiorum and Penicillium italicum, that are responsible for tuber rot during storage. The tubers were treated with clove (Syzygium aromaticum L. Merr\& Perry.) or caraway (Carum carviL.) oils at $5 \mathrm{mll}^{-1}$, wrapped with perforated polyethylene and stored at $0^{\circ} \mathrm{C}$ and $90 \%$ relative humidity $(\mathrm{RH})$ or placed in peatmoss layers, and stored at room temperature $\left(25 / 10^{\circ} \mathrm{C}\right.$, day/night $)$ and $70 \%$ RH. Tubers treated with caraway oil, placed in peatmoss and stored at $25 / 10^{\circ} \mathrm{C}$ and $70 \%$ RH suppressed the incidence of sprouting percentage, and decreased weight loss, decay, compared with the control, as well as, increased dry matter content, carbohydrates, inulin, protein, total phenols and activity of peroxidase and polyphenol oxidase. This treatment showed noticeable reduction of rot disease on the artificially infected tubers under storage, as compared with chemical treatment, suggesting the use of caraway oil and peatmoss layer when storing JA tubers at room temperature, to prevent the use of pesticide and saving cooling energy.
\end{abstract}

Jerusalem artichoke (Helianthus tuberosus L.) is an economic plant, because of possibilities of cultivation on marginal land with high productivity. The high sugars content, primarily inulin, of Jerusalem artichoke is a good source of fructose, which is useful in food industry and for pharmaceuticals (BenChekroun et al., 1994). Tubers contain 20.4 - 31.9\% of dry matter, mainly carbohydrates, which consist of water-soluble inulin (50-56\% of dry matter), its derivatives (fructo-oligosaccharides), reducing sugars (fructose and glucose) and sucrose. Tubers contain also dietary fiber, i.e. insoluble cellulose fractions (cellulose and lignin), pectin and hemi cellulose (soluble cellulose fraction) (Cieślik et al., 2005). Due to the tendency to vegetable production diversification, Jerusalem artichoke is a good candidate as a valuable vegetable, its popularity increases in the world, but so far not very popular in Egypt. 
Some cultivars are much more susceptible to storage losses, but there are very few reports on the influence of storage conditions on quality changes. Troubles in storage can result from the fact that tubers lack of a corky surface layer, similar to that found on potatoes, which reduce transpiration, but have a thin, easily damaged surface that permits rapid water loss (Saengthobpinit and Sajjaanantakul, 2005). Beside the quality degradation, tubers undergo significant alterations in carbohydrate chemistry during storage, which can affect tubers marketability. Inulin consists of a series of molecules of varying chain length, which depolymerized during storage of tubers, whether harvested or left in situ (Schorr-Galindo and Guiraud, 1997).

Jerusalem artichoke plants carry pathogens and can start the spoilage in the field, although actual proliferation and substantial spoilage can occur only after harvest when the main plant defenses are reduced or eliminated (Jin et al., 2013). Under storage conditions, approximately 20 organisms have been shown to cause JA tuber rots, although losses can be circumvented through proper storage conditions. Among them, watery soft rot caused by Sclerotinia sclerotiorum often develops on tubers that appear sound at harvest but subsequently succumb in storage. Sclerotium rot caused by Sclerotium rolfesii is a serious tuber rot in the field and storage. Blue mold rot caused by Penicillium results in decay only at relatively high temperatures (e.g. $20^{\circ} \mathrm{C}$ ) (Kays and Nottingham, 2008). Therefore, simple, not costly storage technologies of Jerusalem artichoke to reduce losses are demanded.

Usually, simple methods of tubers storage are applied, for example overwintering of tubers in an open field or regular storehouses. Overwintering is not costly, but technologically risky method, since in a colder climate, some freezing injuries may occur, and it is impossible to pick up the tubers from the soil during winter (Schorr-Galindo and Guiraud, 1997). In cold stores tubers of Jerusalem artichoke can be kept at the temperature of 0 to $2^{\circ} \mathrm{C}$ and RH 90 to $95 \%$ for several months. Additionally, many fungi can grow at low temperatures and cause substantial damage, especially if the fruits are stored for extended periods of time (Tesio et al., 2011). However, storage of the harvested tubers usually results in high losses in quality, caused mainly by desiccation, rotting, sprouting, freezing, and inulin degradation.

The use of synthetic fungicides could prevent spoilage to some degree, but some fungi could become resistant to commonly used pesticides (Wang et al., 2011). In addition, attempts to reduce chemical contamination of the environment as well as health hazards associated with consumption of pesticide residues dictate the reduction of the use of such chemicals (Tournas and Katsoudas, 2005). Alternative natural organic sources to prevent tuber sprouting have been investigated (Hartmans et al., 1995). S-(+)-carvone is an organic compound obtained from caraway seeds, it is widely used to prevent sprouting of potato tuber (Hatmans et al., 1995). The essential oil of clove extracted from dried buds of Syzygium aromaticum (eugenol) was also used in control potato sprouting in long-term storage. These natural oils slowly release active substances during the storage and they may contain a wider range of useful bioactive compounds.

Egypt. J. Hort. Vol. 42, No.1 (2015) 
This study is a trial to introduce natural effective and ecofriendly way to store the tubers of Jerusalem artichoke using clove and caraway oils and increase shelf life, nutritive value, quality and storability, as well as protecting the tubers from the pathogenic fungi, Sclerotium rolfesii, Sclerotinia sclerotiorum and Penicillium italicum, that responsible for tuber rot at storage .

\section{Materials and Methods}

An experiment was performed in 2012/2013 and 2013/2014 on Jerusalem artichoke cultivar 'Fuseau, were grown at the Baramoon Experimental Farm (latitude $30^{\circ} 11^{\prime} \mathrm{N}$, longitude $28^{\circ} 26^{\prime} \mathrm{E}$ and altitude $+7 \mathrm{~m}$ above sea level) of Mansoura Hort. Res. Sta., Egypt.

Tubers were planted out at the beginning of April, and harvested at the end of November. Tubers were stored for five months, from the beginning of December till the end of April of the next year. Three fungal isolates (Sclerotium rolfesii, Sclerotinia sclerotiorum and Penicillium italicum) were selected, as they were the most common in our survey, as well as worldwide known post-harvest pathogenic fungi on JA tubers. The fungal isolates were tested for their pathogenicity using tuber inoculation technique. Each fungal isolate was cultured on potato dextrose agar (PDA) media in Petri-dishes and incubated for 3 days in the dark at $24 \pm 2{ }^{\circ} \mathrm{C}$ for Penicillium italicum at $15 \pm 2^{\circ} \mathrm{C}$ for Sclerotium rolfesii and Sclerotinia sclerotiorum. When hyphal growth reached a diameter of $3 \mathrm{~cm}$, a 0.5 $\mathrm{cm}$ disk was removed from each culture and transferred to $250 \mathrm{ml}$ almoner flask containing $50 \mathrm{ml}$ of PD broth medium. The cultures were incubated in the dark for 10 days until the hyphal mat covered the open surface of the liquid medium, then harvested and washed gently in sterile distilled water. Twenty grams of fresh mat of each fungus was taken, mixed thoroughly and blended in $1000 \mathrm{ml}$ of distilled water to produce a homogenized suspension. Healthy tubers were separately washed, surface-disinfected for $3 \mathrm{~min}$ in $0.5 \%(\mathrm{v} / \mathrm{v})$ sodium hypocholorite, rinsed by sterilized water. Tubers were separated into two groups, the first group was treated twice with essential oils (caraway and clove at $5 \mathrm{ml} \mathrm{l}^{-1}$, at the beginning and 70 days after storage) and Benzothiadiazole (BTH) $(70 \%)$ at a rate of $2.5 \mathrm{~g} \mathrm{l}^{-1}$, compared with the control, and the second group was infected with the three pathogenic fungi and were treated with the same treatments as mentioned in first group. Benzothiadiazole (Benzo- $(1,2,3)$ thiadiazole-7-carbothioic acid S-methyl ester wetta-ble granule 50\% WG, Bion $^{\circledR}$ ) was use in this experiment as a chemical treatment. Both groups were stored in a chamber with controlled temperature, at the temperature of $0^{\circ} \mathrm{C}$ and RH $90-95 \%$, and kept in perforated polyethylene (0.075 mm thickness) bags, capacity of $10 \mathrm{~kg}$, and the other group of tubers kept in bags with moist peatmoss layer at the rate of $1.5 \mathrm{~kg}$ per $1 \mathrm{~kg}$ tuber and stored at ambient temperature $\left(25 / 10^{\circ} \mathrm{C}\right.$ day/night). The peat was kept moisture during storage period, to obtain high humidity inside the bulk (near $100 \% \mathrm{RH}$ ). The experiment was done in three replications, with $30 \mathrm{~kg}$ of tubers in each using two way completely randomized design. 


\section{Data recorded}

In the experiment, recorded data indicated: Sprouting, weight losses and decay of tubers (in \%). Dry matter (\%) of the tuber was determined by drying in a hot-air oven at $105^{\circ} \mathrm{C}$ for $24 \mathrm{~h}$ (AOAC, 1990). Samples of tubers were analyzed for inulin and carbohydrate composition after harvest and the end of storage according to Winton and Winton (1958) and Dubois et al. (1956), respectively, protein according to Robinson (1973). Total phenol extraction of phenolic compounds was determined according to the methods described by Daniels and George (1972). Polyphenoloxidase and peroxidase were determined according to Yamazaki and Biette (1963), respectively.

\section{Essential oils extraction}

Seeds of caraway and clove flower buds (200 g from each one) used for oil extraction by hydro-distillation for 2-3 hr. according to Chialva et al. (1982) and Charles and Simon (1990). After extraction, essential oils were GLC analyzed to separate and identify their basic constituents according to El-Deeb et al. (1993). Benzothiadiazole (Benzo-(1,2,3) thiadiazole -7- carbothioic acid S-methyl esterwettable granule 50\% WG, BionR), was used in this experiment.

\section{Statistical analysis}

Data obtained were subjected to statistical analysis using analysis of variance according to Snedecor and Cochran (1982). The treatments means were compared using the least significant differences (LSD) at $5 \%$ level of probability as described by Steel and Torrie (1980) .

\section{Results and Discussion}

The storage method of Jerusalem artichoke Effect of interaction

Data in Table 2 and Photos 1, 2 and 3 show the effect of interaction between storage temperatures and application of fungicide (BTH) and essential oils with or without induced infection with pathogenic fungi, Sclerotium rolfesii, Sclerotinia sclerotiorum and Penicillium italicum on storage recorded parameters in Jerusalem artichoke (JA) tubers. Results indicate that treated JA tubers with BTH and clove or caraway oils with or without induced infection under low or high temperature resulted in the lowest values of sprouting, weight loss and decay compared with the control (no induced infection) during two seasons. There were no significant effects on storage recorded parameters when deteriorates clove or caraway oil was used. The other control treatment were tubers pathogenic fungi (Sclerotium rolfesii, Sclerotinia sclerotiorum and Penicillium italicum) totally deteriorated at the begin of experiment (Photo 6). These advantages effects of the interaction treatments could be attributed to their effect on preservation of tuber, internal bio-constituents. The essential oil monoterpenes as carvone known to suppress sprouting of tubers via their inhibition role on mitochondria respiration and reducing carbohydrate degradation and sugars changes (Daniels et al., 1996). Also the applied clove oil was rich in phenolic antioxidants (Table 1), which may suppress the oxidative

Egypt. J. Hort. Vol. 42, No.1 (2015) 
stress destructive effects and in turn allowing less available energy and mobilized reserves, reducing sprouting and weight losing incidence (Frazier et al., 2006). On the other hand, control treatments were stored on $0^{\circ} \mathrm{C}$ and $25^{\circ} \mathrm{C}$ showed at the end of storage high values of sprouting 90.00, 90.97 and 100.00, $100.00 \%$, in the two seasons, respectively as well as weight loss and decay percentages. The pronounced worst storability of control tubers includes progressive sprouting, weight loss and damage incidence. This could be interpreted based on the same previously mentioned considerations. Since, it can be suggested that, the control tubers had less or no capabilities to protect and preserve themselves against such stress effects.

Application of sand or peat for storage bags significantly decreased weight loss of tubers without signs of spoilage or sprouting. Tubers stored in the sand or the peats for 4 months were still firm and crispy and had good high quality. Therefore, storage in the sand or in the peat, which allows maintaining high firmness, is one of the most important traits of Jerusalem artichoke quality, should be recommended for storage (Danilčenko et al., 2008).

TABLE 1. The volatile compounds identified in the n-hexan extract of clove and caraway oils by using GLC .

\begin{tabular}{|c|l|l|l|l|l|}
\hline \multicolumn{3}{|c|}{ Clove oil } & \multicolumn{3}{c|}{ Caraway oil } \\
\hline No. & Compounds & Con. \% & No. & Compounds & Con. \% \\
\hline 1 & p-cymene & 0.90 & 1 & Myrcene & 0.48 \\
\hline 2 & 5 -hexene-2-one & 0.67 & 2 & Limonene & 35.50 \\
\hline 3 & Thymol & 0.87 & 3 & $\alpha$-Terpinolene & 0.10 \\
\hline 4 & Eugenol & 71.56 & 4 & Trans limonene oxide & 2.01 \\
\hline 5 & Eugenol acetate & 8.99 & 5 & Trans dihydro carvone & 0.33 \\
\hline 6 & Caryophyllne oxide & 1.67 & 6 & Trans carvol & 0.31 \\
\hline 7 & Guail & 0.90 & 7 & Carvone & 57.70 \\
\hline 8 & Benzene-1-butylheptyl & 0.55 & 8 & Perilla alochol & 1.48 \\
\hline 9 & Nootkatin & 10.05 & 9 & Carvacrol & 0.34 \\
\hline 10 & Isolongifolanone (trans) & 0.86 & 10 & $\beta$-caryophyllene & 0.41 \\
\hline 11 & Hexadecanoic acid & 0.50 & -- & ------ & --- \\
\hline 12 & Vitamin E acetate & 0.43 & -- & ------ & --- \\
\hline
\end{tabular}

\section{Effect of BTH and essential oils}

The same results in Table 2 also indicate that the essential oils treatments greatly suppressed the incidence of sprouting, weight loss and decay parameters followed by BTH, compared with the control, photos (4,5 and 6).Clove and caraway oil showed zero sprouting, weight loss and decay (no significance between them), followed by BTH in this respect (Table 2). The interaction treatments of clove or caraway oils with or without induced infection gave the best results on storage parameters and reduced pathogen (no significance between no induced infection and induced infection) caused by using of clove and caraway oils. Caraway oil of monoterpenes is 
rich of carvone (Table 1). S-carvone is a naturally occurring volatile with interesting properties that can be commercially exploited. The use of S-carvone is based on a wide range of biological effects occurring in different unrelated organisms. Potato sprout growth is affected by low concentrations of S-carvone in the head space as well as in potato tubers. The observed growth inhibition of potato sprouts and of sprouting of potato tubers could not be explained by inhibition of respiratory processes. Probably more specific effects of S-carvone play a role in the sprout growth of potato tubers, such as inhibition of the key enzyme in the mevalonate pathway, HMGR. Mevalonate, known to be the main pathway of gibberellin biosynthesis (Oosterhaven et al., 1993). Fungi are also inhibited by S-carvone, but various organisms are able to convert it into less toxic compounds (Oosterhaven et al., 1995). Eugenol is main component of clove oil. Pepeljnjak et al. (2003) pointed out that eugenol is one of the strongest inhibitors of enzyme processes and related compounds as methyle- or actyl eugenol could change this property. Antimicrobial activity of this oil can be attributed to the presence of an aromatic nucleus and a phenolic $\mathrm{OH}$ group that are known to be reactive and can form hydrogen bonds with-SH group in the active sites of target enzymes, resulting in deactivation of enzymes in fungi (Velluti et al. 2003, Alma et al., 2007). The sites and number of hydroxyl groups on the phenol group are thought to be related to the irrelative toxicity to microorganisms, with evidence that increased hydroxylation results in increased toxicity, Photos (1,2 and 3).

\section{Effect of temperature}

The tuber stored on $0^{\circ} \mathrm{C}$ significantly recorded low sprouting, weight loss and decay as compared with storage tuber at high temperature $\left(25^{\circ} \mathrm{C}\right)$. Our results are in agreement with those reported by Danilčenko et al, 2008, who found that tuber stored at $2^{\circ} \mathrm{C}$ for 120 days were still firm and crisp, and no sign of sprouting or spoilage. Most enzymatic and chemical reactions were drastically reduced or stopped at freezing temperature, while Jerusalem artichoke tissue metabolism could be continue at a slow rate, even at $2^{\circ} \mathrm{C}$ storage temperature. At high temperature stressful factor induce generation of elevated components for the level of the toxic and degradable reactive oxygen species (ROS) within stressed tissues (Bowler et al., 1992). Also, they found that high storage temperature accelerate respiration rate and other metabolic activities such as carbohydrate reserves degraded to sugars to provide energy and structural rapidly developing sprout tissues, which sprouts serves as a powerful sink for the mobilized sugars.

\section{Biochemical characters \\ Effect of interaction}

The applied essential oils and BTH gave higher bio-constituents during the storage period of tuber that stored on $0^{\circ} \mathrm{C}$ and $25^{\circ} \mathrm{C}$ with or without induced infection compared with those of untreated tubers, in both seasons (Table 3). Caraway and clove oils applied to tubers (JA) gave the highest dry matter, total carbohydrate, inulin and protein contents (no significant among them) in the tubers stored on $0^{\circ} \mathrm{C}$ and $25^{\circ} \mathrm{Cwith}$ or without induce infection, followed by BTH, in both seasons.

Egypt. J. Hort. Vol. 42, No.1 (2015) 
ENHANCEMENT OF QUALITY AND STORABILITY ...

TABLE 2. Effect of storage temperature and essential oils plus BTH on tuber storage behavior of Jerusalem artichoke at 0 and 150 DAS in 2012/13 and 2013/14 seasons.

\begin{tabular}{|c|c|c|c|c|c|c|c|c|c|}
\hline \multirow{2}{*}{ No. } & \multicolumn{3}{|r|}{ Treatments } & \multicolumn{2}{|c|}{$\begin{array}{c}\text { Sprouting } \\
(\%)\end{array}$} & \multicolumn{2}{|c|}{$\begin{array}{c}\text { Weight losses } \\
(\%)\end{array}$} & \multicolumn{2}{|c|}{$\begin{array}{c}\text { Decay } \\
(\%)\end{array}$} \\
\hline & \multicolumn{2}{|c|}{$\begin{array}{c}\text { Storage } \\
\text { temperature }\end{array}$} & $\begin{array}{c}\text { (Essential oils+BTH) X } \\
\text { Pathogen }\end{array}$ & 2012/13 & $2013 / 14$ & $2012 / 13$ & $2013 / 14$ & $2012 / 13$ & 2013/14 \\
\hline-- & \multicolumn{3}{|r|}{ Zero Time } & 0.00 & 0.00 & 0.00 & 0.00 & 0.00 & 0.00 \\
\hline 1 & \multirow{7}{*}{ 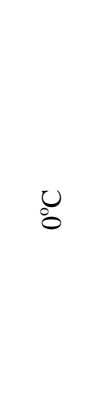 } & \multicolumn{2}{|c|}{ Control } & 90.00 & 90.79 & 70.3 & 68.50 & 35.86 & 34.43 \\
\hline 2 & & \multicolumn{2}{|c|}{ BTH + No induced infection } & 65.3 & 69.65 & 19.83 & 16.82 & 25.65 & 23.84 \\
\hline 3 & & \multicolumn{2}{|c|}{ BTH + induced infection } & 70.65 & 70.03 & 25.66 & 24.25 & 28.61 & 25.83 \\
\hline 4 & & \multicolumn{2}{|c|}{$\begin{array}{l}\text { Clove oil + No induced } \\
\text { infection }\end{array}$} & 2.24 & 1.23 & 1.48 & 1.20 & 0.54 & 0.42 \\
\hline 5 & & \multicolumn{2}{|c|}{ Clove oil + induced infection } & 3.40 & 1.32 & 3.33 & 2.89 & 0.59 & 0.25 \\
\hline 6 & & \multicolumn{2}{|c|}{$\begin{array}{l}\text { Caraway oil + No induced } \\
\text { infection }\end{array}$} & 0.00 & 0.00 & 0.00 & 0.00 & 0.00 & 0.00 \\
\hline 7 & & \multicolumn{2}{|c|}{ Caraway oil + induced infection } & 1.43 & 0.88 & 1.65 & 1.15 & 0.31 & 0.29 \\
\hline \multicolumn{4}{|c|}{ Means $\left(0^{\circ} \mathrm{C}\right.$ Temperature $)$} & 34.00 & 33.32 & 17.07 & 16.40 & 13.08 & 12.18 \\
\hline 8 & \multirow{7}{*}{ in } & \multicolumn{2}{|c|}{ Control } & 100.0 & 100.0 & 78.60 & 79.99 & 65.54 & 60.34 \\
\hline 9 & & \multicolumn{2}{|c|}{ BTH + No induced infection } & 75.0 & 78.30 & 22.50 & 20.30 & 48.23 & 47.0 \\
\hline 10 & & \multicolumn{2}{|c|}{ BTH + induced infection } & 83.0 & 86.0 & 29.95 & 28.68 & 59.65 & 60.12 \\
\hline 11 & & \multicolumn{2}{|c|}{$\begin{array}{l}\text { Clove oil + No induced } \\
\text { infection }\end{array}$} & 0.95 & 0.44 & 0.99 & 0.40 & 0.32 & 0.29 \\
\hline 12 & & \multicolumn{2}{|c|}{ Clove oil + induced infection } & 1.42 & 0.92 & 1.42 & 0.64 & 0.43 & 0.32 \\
\hline 13 & & \multicolumn{2}{|c|}{$\begin{array}{l}\text { Caraway oil + No induced } \\
\text { infection }\end{array}$} & 0.00 & 0.00 & 0.00 & 0.00 & 0.00 & 0.00 \\
\hline 14 & & \multicolumn{2}{|c|}{ Caraway oil + induced infection } & 0.00 & 0.00 & 0.00 & 0.00 & 0.00 & 0.00 \\
\hline \multicolumn{4}{|c|}{ Means $\left(25^{\circ} \mathrm{C}\right.$ Temperature) } & 37.19 & 37.94 & 19.07 & 18.57 & 24.88 & 24.01 \\
\hline \multirow{7}{*}{\multicolumn{2}{|c|}{$\begin{array}{c}\text { (Essential oils } \\
+ \text { BTH) } x \\
\text { Pathogen }\end{array}$}} & \multicolumn{2}{|c|}{ Control } & 97.5 & 95.40 & 74.45 & 74.26 & 50.0 & 47.38 \\
\hline & & \multicolumn{2}{|c|}{ BTH + No induced infection } & 70.15 & 73.96 & 21.17 & 18.56 & 36.94 & 35.42 \\
\hline & & \multicolumn{2}{|c|}{ BTH + induced infection } & 96.83 & 78.02 & 27.81 & 26.47 & 44.13 & 42.97 \\
\hline & & $\begin{array}{l}\text { Clo } \\
\text { infe }\end{array}$ & $\begin{array}{l}\text { e oil + No induced } \\
\text { ction }\end{array}$ & 1.60 & 0.84 & 1.24 & 0.80 & 0.43 & 0.34 \\
\hline & & Clo & ve oil + induced infection & 2.41 & 1.12 & 2.38 & 1.77 & 0.51 & 0.39 \\
\hline & & $\begin{array}{l}\text { Car } \\
\text { infe }\end{array}$ & $\begin{array}{l}\text { way oil + No induced } \\
\text { ction }\end{array}$ & 0.00 & 0.00 & 0.00 & 0.00 & 0.00 & 0.00 \\
\hline & & Car & away oil + induced infection & 0.72 & 0.44 & 1.24 & 0.58 & 0.16 & 0.15 \\
\hline LSD & & & & \# & $\#$ & $\#$ & $\#$ & \# & \# \\
\hline Inter & tions & & & 3.99 & 2.64 & 0.52 & 0.97 & 2.16 & 0.97 \\
\hline Stora & e Temper & ature & & $* * *$ & $* * *$ & $* * *$ & $* * *$ & $* * *$ & $* * *$ \\
\hline (Esse & tial oils + & $\overline{\mathrm{BTH}}$ & x Pathogen & 2.82 & 1.87 & 0.37 & 0.683 & 1.53 & 3.98 \\
\hline
\end{tabular}

Egypt. J. Hort. Vol. 42, No.1 (2015) 


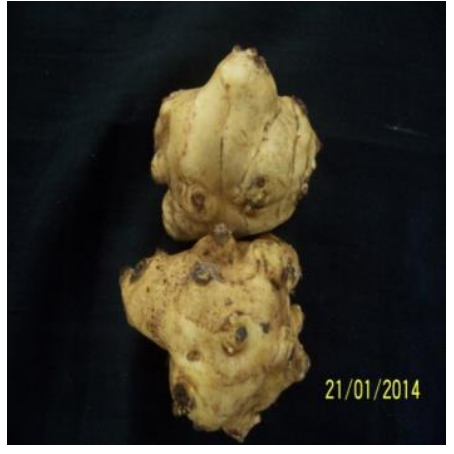

1

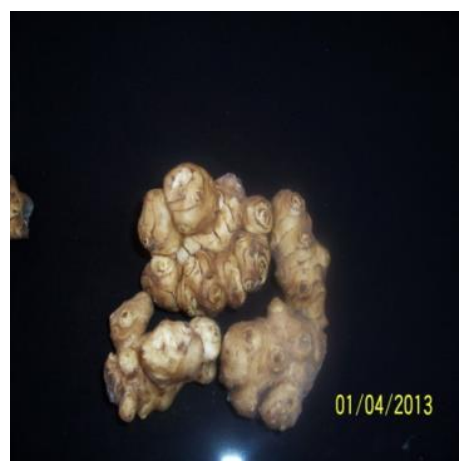

3

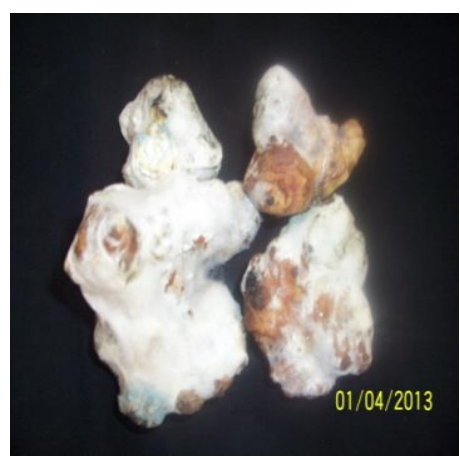

5

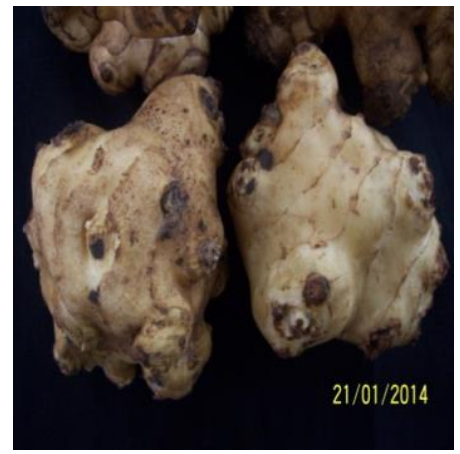

2

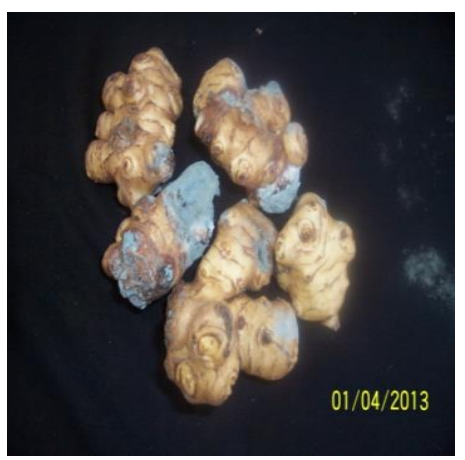

4

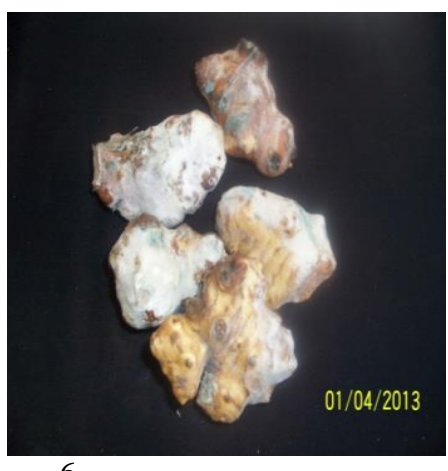

6

Photo 1. Healthy tubers, tubers were treated with caraway oil plus no infection Photo 2. Healthy tubers, tubers were treated with caraway oil plus infection Photo 3. Healthy tubers, tubers were treated with clove oil plus infection Photo 4. Infected tubers with Penicillium italicum, control treatment Photo 5. Infected tubers with Sclerotinia sclerotiorum, control treatment Photo 6. Infected tubers with pathogenic fungi, Sclerotium rolfesii, Sclerotinia sclerotiorum and Penicillium italicum, control treatment .

Egypt. J. Hort. Vol. 42, No.1 (2015) 
Data from the experiment showed that in freshly harvested Jerusalem artichoke tubers dry matter content reached $18.37,19.46 \%$ and increased by the end of storage $30.90-30.94 \%$ at $25^{\circ} \mathrm{C}$ (Table 3), in two seasons, respectively. Due to a considerably higher transpiration, dry matter of Jerusalem artichoke tubers stored in PP net bags was higher than in tubers kept in the sand or the peat. Irrespective of storage conditions, dry matter of Jerusalem artichoke tubers increased by the end of storage period, and in tubers kept in PP net bags dry matter was higher than in tubers stored in the peat (Danilčenko et al., 2008).

Carbohydrates are the main chemical compounds found in Jerusalem artichoke tubers. Results showed that total carbohydrates concentration in freshly harvested tubers reached 56.22 and $5599 \mathrm{mg} / \mathrm{g}$ D.W. By the end of storage, content decreased to 55.30 and $55.40 \mathrm{mg} / \mathrm{g} \mathrm{D}$.W., respectively, (Table 3). Similar treated was obtained with inulin and total protein (Table 3). The study made by Ben-Chekroun et al. (1994) on the Fuseau variety has shown that after the third week of storage, the decrease in the content of total carbohydrate was evaluated at $0.98 \%$ of the fresh weight/week of storage. On the other hand, use of plant extract reduced starch degradation and sugar changes (Daniels et al., 1996). In contrary, control treatments stored on $0{ }^{\circ} \mathrm{C}$ and $25^{\circ} \mathrm{C}$ showed, at the end of storage, that content decreased to $40.12-42.18$ and $39.83-40.88 \mathrm{mg} / \mathrm{g} \mathrm{D.W.}$., respectively, in two seasons. In control treatments, dramatically degradation and depletion in its tuber carbohydrates and other bio-constituent could be explained based on the harmful and degradable effects of high temperature / oxidative stress. Such case might be induced generation of elevated toxic level of oxygen radicals (Bowler et al., 1992)

\section{Effect of BTH and essential oils}

All storage treatments significantly surpassed the control in their tuber bioconstituents, i.e., dry matter, total carbohydrate, inulin and protein, in the both seasons (Table 3). The highest dry matter and inulin contents were shown by caraway oil with or without induced infection compared with the other treatments, in both seasons. Caraway and clove oils with or without induced infection, gave the highest total carbohydrate and protein (with no considerable differences between them) followed by BTH in the two seasons. Such essential oils monoterpenes were shown in Table 1. Carvone (57.70\%) and Limonene $(35.50 \%)$ are the major compounds of caraway oil. Meanwhile, their rich antioxidants content (Table 1) eugenol (71.56\%), eugenol acetate $(8.99 \%)$ and thymol $(0.87 \%)$ of clove oil as compared with synthetic antioxidants such as butylate dehydroxyl toluene (BHT), Davies (1990) who indicated that basic constituents (monoterpenes and antioxidants) tended to slow down the activity of carbohydrates and protein breakdown associated enzymatic systems as well as respiration and energy metabolism enzyme.

Egypt. J. Hort. Vol. 42, No.1 (2015) 


\section{Effect of temperature}

The cold storage $\left(0^{\circ} \mathrm{C}\right)$ was of significant by higher dry matter in the second season only compared with storage tuber at high temperature $\left(25^{\circ} \mathrm{C}\right)$, but in the first season no considerable differences were found between them (Table 3). Stored tubers on $25^{\circ} \mathrm{C}$ gave significant the highest carbohydrate and inulin contents, in both seasons. No considerable differences between them on protein content of tuber, in the two seasons.

Other authors reported that dry matter content in Jerusalem artichoke tubers depended upon many factors, such as cultivar, maturity stage and storage conditions. Tubers kept for 30 days at temperature of $18^{\circ} \mathrm{C}$ can lose above $20 \%$ of water (Cabezas et al., 2002).

Most enzymatic and chemical reactions were drastically reduced or stopped at freezing temperatures, while Jerusalem artichoke tissue metabolism could continue at a slow rate, even at $2^{\circ} \mathrm{C}$ storage temperature. Cold storage would therefore retards undesirable changes in the inulin characteristics for a certain period of time, e.g. 4 weeks at $5^{\circ} \mathrm{C}$ in this study. Frozen storage would maintain Jerusalem artichoke tubers and their inulin quality for a much longer time. Modler et al. (1993) also found that higher storage temperature encouraged breakdown of inulin and utilization of monosaccharide formed from the breakdown, presumably due to higher respiration and other metabolic activities .

\section{Total phenol and enzyme activity}

Effect of interaction

Data in Table 4 show that all interaction treatments induced higher total phenol and activity for peroxidase and diphenol oxidase enzymes of their tubers than control, in the two seasons. Also data cleared that among storage treatments, clove and caraway oils were considerably increased total phenol and the activity of polyphenol oxidase (with no significant differences among them, in the two seasons), whereas those tubers treated with caraway oil and storage at low or higher temperatures with or without induced infection gave the highest significant peroxidase activity in both seasons.

Higher temperature storage condition as a stress factor, induce more serious internal oxidative stress, generation of elevated level of degradable and toxic reactive oxygen species (ROS) $\left(\mathrm{O}^{-2}, \mathrm{OH}^{-}\right.$and $\left.\mathrm{H}_{2} \mathrm{O}_{2}\right)$. The enzymatic defense against high temperature inducible oxidative stress is of great importance and depending on the activation degree of peroxidase and diphenol oxidase as affected by storage treatments. Such enzymatic activation could be directly depending on the essential oils content of the antioxidant phenols eugenol (71.56\%), eugenol acetate $(8.99 \%)$ and thymol $(0.87 \%)$ of clove oil (Table 1$)$. On the other hand, the remarkable inducible effect of low temperature $\left(4^{\circ} \mathrm{C}\right)$ treatment on the activity of peroxidase and diphenol oxidase may be explained based on the findings of Rojas et al. (2000). They stated that long term exposure to low temperature below $10^{\circ} \mathrm{C}$ also induces generation of certain levels of ROS sufficient to activate the antioxidant enzymes to be protected against the subsequent accumulation of ROS.

Egypt. J. Hort. Vol. 42, No.1 (2015) 
ENHANCEMENT OF QUALITY AND STORABILITY ..

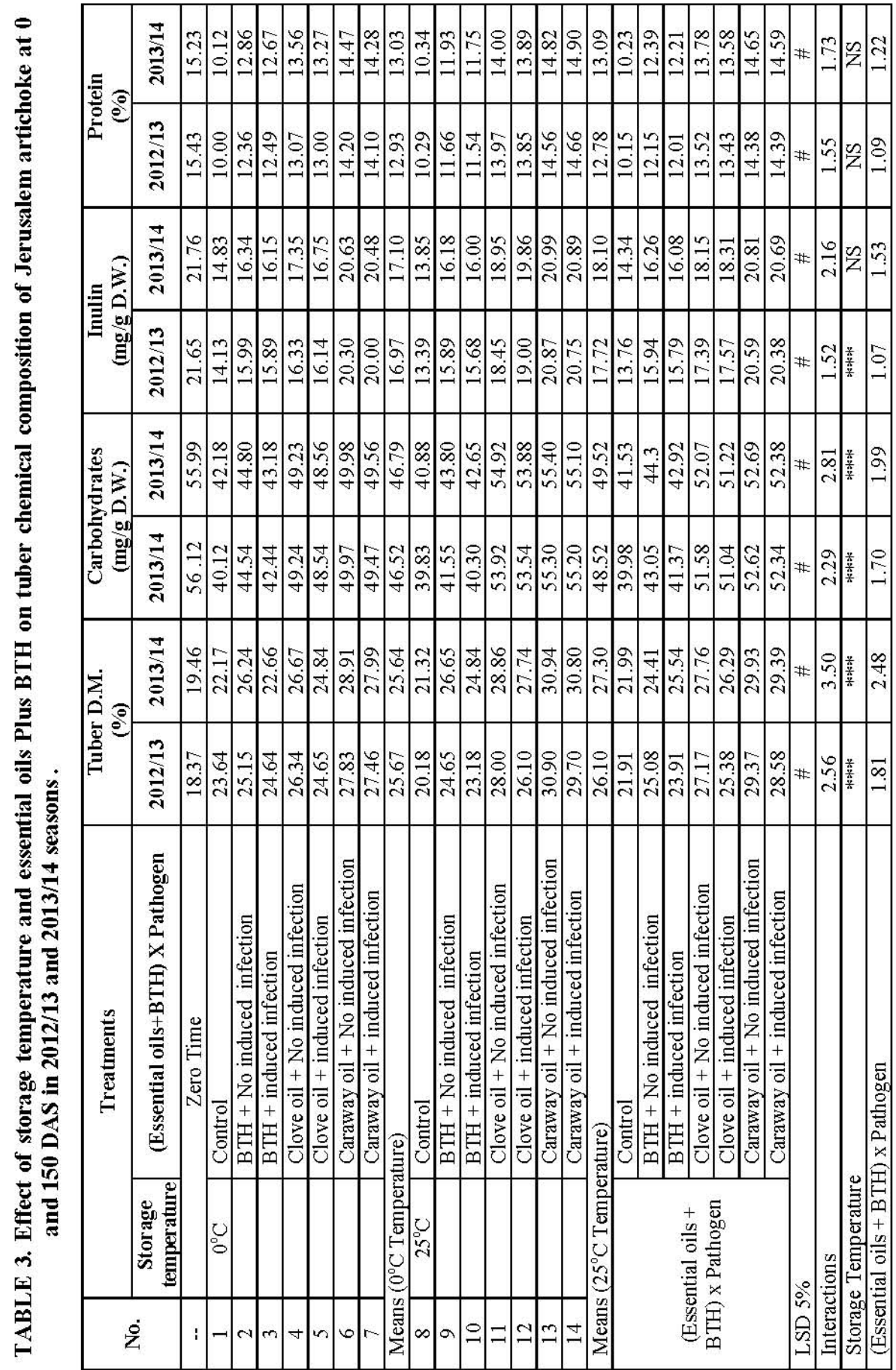

Egypt. J. Hort. Vol. 42, No.1 (2015) 


\section{Effect of BTH and essential oils}

The same data indicate that caraway and clove oils had a significant effect on total phenol content, in the two seasons, whereas caraway oil only gave the highest values of polyphenoloxidase and peroxidase activities in comparison with other treatments in both seasons of study (Table 4).

It was observed that the scavenging activity of volatile of clove buds might be due to the higher concentration of phenolic compounds such as eugenol (71.56\%), eugenol acetate $(8.99 \%)$ and thymol $(0.87 \%)$ in comparison with BHT $(70 \%)$ at $50 \mathrm{mg} / \mathrm{ml}$.

Our results are consistence with those of Miller (1996), who found that quercetin scavenges oxygen-free radicals, and inhibits the enzyme xanthine oxidase. Among the tested extracts, the ethanol extract of the clove buds showed remarkable scavenging activity (93\%), as compared with synthetic antioxidants such as BHT $(95 \%)$. These results demonstrated that the extracts of $S$. aromaticum buds and the isolated flavonoids have effective activity as hydrogen donors and as primary antioxidants by reacting with lipid radicals. (Chaieb et al., 2007)

\section{Effect of temperature}

No significant differences in total phenol tuber contents were found between cold storage $\left(0^{\circ} \mathrm{C}\right)$ and high temperature $\left(25^{\circ} \mathrm{C}\right)$ in both seasons (Table 4). Storing tuber at high temperature $\left(25^{\circ} \mathrm{C}\right)$ significantly increased polyphenol oxidase peroxidase activities, in the two seasons compared with the cold storage $0^{\circ} \mathrm{C}$.

Most enzymatic and chemical reactions are drastically reduced at low temperature, while Jerusalem artichoke tubers metabolism could continue at a slow rate even at the temperature of $2^{\circ} \mathrm{C}$ during storage (Saengthobpinit and Sajjaanantakul, 2005). The greatest differences in the quality of stored Jerusalem artichoke tubers resulted from storage conditions.

Application of the peat as the cover for storage strongly affected the rate of transpiration. Tubers of Jerusalem artichoke have a thin and delicate skin and after harvest they are sensitive to water escape. Herein, it was demonstrated that group of enzymes such as peroxidases, catalases and dismutases known as antioxidant enzymes, that act in presence of metallic and organic activators, i.e. $\mathrm{Zn}, \mathrm{Cu}, \mathrm{Mn}$, phenols, ascorbate, glutathione and etc. as well as in integration with some oxidases such as diphenols oxidase for degrading and scavenging of the injurious elevated levels of oxygen free radicals $\left(\mathrm{H}_{2} \mathrm{O}_{2}, \mathrm{OH}^{-}, \mathrm{O}_{2}\right)$, which generated (oxidative stress) during the exposure to the environmental extremes, high and low temperatures, (Rojas et al., 2000).

Egypt. J. Hort. Vol. 42, No.1 (2015) 
ENHANCEMENT OF QUALITY AND STORABILITY ...

TABLE 4. Effect of storage temperature and essential oils plus BTH on total phenols and enzymes activity of Jerusalem artichoke tubers at 0 and 150 DAS in 2012/13 and 2013/14 seasons .

\begin{tabular}{|c|c|c|c|c|c|c|c|c|}
\hline \multirow[t]{2}{*}{ No. } & \multicolumn{2}{|r|}{ Treatment } & \multicolumn{2}{|c|}{$\begin{array}{l}\text { Total phenols } \\
\text { (\%) }\end{array}$} & \multicolumn{2}{|c|}{$\begin{array}{l}\text { Polyphenol } \\
\text { oxidase } \\
(\%)\end{array}$} & \multicolumn{2}{|c|}{$\begin{array}{l}\text { Peroxidase } \\
\quad(\%)\end{array}$} \\
\hline & \begin{tabular}{|c|}
$\begin{array}{c}\text { Storage } \\
\text { temperature }\end{array}$ \\
\end{tabular} & $\begin{array}{c}\text { (Essential oils+BTH) } \mathrm{X} \\
\text { Pathogen }\end{array}$ & $2012 / 13$ & 2013/14 & 2012/13 & 2013/14 & $2012 / 13$ & 2013/14 \\
\hline-- & & Zero Time & 0.223 & 0.212 & 0.398 & 0.432 & 0.396 & 0.399 \\
\hline 1 & \multirow{7}{*}{ ¿ } & Control & 0.259 & 0.243 & 0.391 & 0.412 & 0.387 & 0.392 \\
\hline 2 & & $\begin{array}{l}\text { BTH + No induced } \\
\text { infection }\end{array}$ & 0.345 & 0.349 & 0.431 & 0.583 & 0.510 & 0.564 \\
\hline 3 & & BTH + induced infection & 0.323 & 0.324 & 0.454 & 0.496 & 0.483 & 0.483 \\
\hline 4 & & $\begin{array}{l}\text { Clove oil + No induced } \\
\text { infection }\end{array}$ & 0.551 & 0.556 & 1.419 & 1.422 & 1.980 & 1.999 \\
\hline 5 & & $\begin{array}{l}\begin{array}{l}\text { Clove oil + induced } \\
\text { infection }\end{array} \\
\end{array}$ & 0.542 & 0.547 & 1.417 & 1.431 & 1.650 & 1.834 \\
\hline 6 & & $\begin{array}{l}\text { Caraway oil + No induced } \\
\text { infection }\end{array}$ & 0.646 & 0.649 & 1.461 & 1.483 & 2.690 & 2.693 \\
\hline 7 & & $\begin{array}{l}\text { Caraway oil + induced } \\
\text { infection }\end{array}$ & 0.634 & 0.638 & 1.465 & 1.486 & 2.650 & 2.565 \\
\hline \multicolumn{3}{|c|}{ Means $\left(0^{\circ} \mathrm{C}\right.$ Temperature $)$} & 0.495 & 0.444 & 1.038 & 1.047 & 1.478 & 1.517 \\
\hline 8 & \multirow{7}{*}{ in } & Control & 0.339 & 0.323 & 0.372 & 0.382 & 0.211 & 0.245 \\
\hline 9 & & $\begin{array}{l}\text { BTH + No induced } \\
\text { infection }\end{array}$ & 0.339 & 0.342 & 0.539 & 0.541 & 1.230 & 1.250 \\
\hline 10 & & BTH + induced infection & 0.352 & 0.364 & 0.528 & 0.543 & 1.110 & 1.180 \\
\hline 11 & & $\begin{array}{l}\text { Clove oil + No induced } \\
\text { infection }\end{array}$ & 0.597 & 0.599 & 1.423 & 1.433 & 2.110 & 2.130 \\
\hline 12 & & $\begin{array}{l}\begin{array}{l}\text { Clove oil + induced } \\
\text { infection }\end{array} \\
\end{array}$ & 0.554 & 0.575 & 1.420 & 1.432 & 2.100 & 2.100 \\
\hline 13 & & $\begin{array}{l}\text { Caraway oil + No induced } \\
\text { infection }\end{array}$ & 0.678 & 0.681 & 1.512 & 1.546 & 2.780 & 2.890 \\
\hline 14 & & $\begin{array}{l}\text { Caraway oil + induced } \\
\text { infection }\end{array}$ & 0.654 & 0.663 & 1.476 & 1.478 & 2.730 & 2.850 \\
\hline \multicolumn{3}{|c|}{ Means $\left(25^{\circ} \mathrm{C}\right.$ Temperature $)$} & 0.471 & 0.507 & 1.006 & 1.050 & 1.753 & 1.806 \\
\hline \multirow{7}{*}{\multicolumn{2}{|c|}{$\begin{array}{c}\text { (Essential oils + } \\
\text { BTH) } \mathrm{x} \\
\text { Pathogen }\end{array}$}} & Control & 0.299 & 0.283 & 0.385 & 0.397 & 0.299 & 0.319 \\
\hline & & $\begin{array}{l}\text { BTH + No induced } \\
\text { infection }\end{array}$ & 0.342 & 0.345 & 0.485 & 0.562 & 0.870 & 0.907 \\
\hline & & BTH + induced infection & 0.338 & 0.344 & 0.491 & 0.519 & 0.795 & 0.832 \\
\hline & & $\begin{array}{l}\begin{array}{l}\text { Clove oil + No induced } \\
\text { infection }\end{array} \\
\end{array}$ & 0.551 & 0.577 & 1.421 & 1.427 & 2.045 & 2.064 \\
\hline & & $\begin{array}{l}\begin{array}{l}\text { Clove oil + induced } \\
\text { infection }\end{array} \\
\end{array}$ & 0.548 & 0.561 & 1.418 & 1.440 & 1.875 & 1.967 \\
\hline & & \begin{tabular}{|l}
$\begin{array}{l}\text { Caraway oil + No induced } \\
\text { infection }\end{array}$ \\
\end{tabular} & 0.662 & 0.665 & 1.488 & 1.512 & 2.735 & 2.791 \\
\hline & & $\begin{array}{l}\text { Caraway oil + induced } \\
\text { infection }\end{array}$ & 0.644 & 0.551 & 1.467 & 1.482 & 2.690 & 2.753 \\
\hline \multicolumn{3}{|c|}{ LSD 5\% } & \# & \# & \# & \# & \# & \# \\
\hline \multirow{2}{*}{\multicolumn{3}{|c|}{\begin{tabular}{|l} 
Interactions \\
Storage Temperature
\end{tabular}}} & 0.165 & 0.190 & 0.044 & 0.499 & 0.209 & 0.261 \\
\hline & age Temperatı & ture & NS & NS & $* *$ & ** & $* * *$ & $* * *$ \\
\hline \multicolumn{3}{|c|}{ (Essential oils + BTH) $\times$ Patho } & 0.116 & 0.135 & 0.031 & 0.353 & 0.148 & 0.185 \\
\hline
\end{tabular}

Egypt. J. Hort. Vol. 42, No.1 (2015) 


\section{Tubers rot percentage}

Data of the infected tubers as a response of the artificial inoculation with rot fungi are presented in Table 5. Storage at lower temperature is more pronounced in reducing the infected tubers in both seasons. Moreover, the treatment of tubers by either caraway or clove oil reduced vigorously the rot percentage, even in the presence of the induced infection, irrespective the temperature of storage. However, caraway oil was superior in this respect. Regarding the interaction between both temperature and the other chemical natural treatments, it is clear that the treatment of tubers with caraway and storage at $0^{\circ} \mathrm{C}$ significantly reduced the rot severity, even in the presence or absence of induced infection, compared with the other treatments. Generally, both of the tested oils were efficient at any of the tested temperature of both seasons. BTH was second with relatively high rot incidence, supposing that BTH is not good candidate as a storage preservative for Jerusalem artichoke tubers.

TABLE 5. Reducing the rot percentage of stored tubers by combined application of temperature and some safe compound agents .

\begin{tabular}{|c|c|c|c|}
\hline \multicolumn{2}{|r|}{ Storage type } & \multicolumn{2}{|c|}{$\begin{array}{c}\text { Tuber rot infection } \\
(\%)\end{array}$} \\
\hline Temperature & Compound & $2012 / 2013$ & $2013 / 2014$ \\
\hline \multirow[t]{7}{*}{$0{ }^{\circ} \mathrm{C}$} & Control & $80.0 \mathrm{~b}$ & $84.3 \mathrm{~b}$ \\
\hline & $\mathrm{BTH}+\mathrm{No}$ induced infection & $55.0 \mathrm{e}$ & $61.3 \mathrm{f}$ \\
\hline & BTH + induced infection & $65.0 \mathrm{~d}$ & $70.0 \mathrm{~d}$ \\
\hline & Clove oil + No induced infection & $14.3 \mathrm{hi}$ & $16.3 \mathrm{j}$ \\
\hline & Clove oil + induced infection & $25.7 \mathrm{fg}$ & $30.3 \mathrm{~h}$ \\
\hline & Caraway oil + No induced infection & $7.0 \mathrm{j}$ & 9.71 \\
\hline & Caraway oil + induced infection & $11.0 \mathrm{ij}$ & $14.0 \mathrm{jk}$ \\
\hline \multirow[t]{7}{*}{$25^{\circ} \mathrm{C}$} & Control & $100.0 \mathrm{a}$ & $100.0 \mathrm{a}$ \\
\hline & $\mathrm{BTH}+$ No induced infection & $71.3 \mathrm{c}$ & $64.3 \mathrm{e}$ \\
\hline & $\mathrm{BTH}+$ induced infection & $79.0 \mathrm{~b}$ & $75.0 \mathrm{c}$ \\
\hline & Clove oil + No induced infection & $19.3 \mathrm{~h}$ & $23.7 \mathrm{i}$ \\
\hline & Clove oil + induced infection & $31.3 \mathrm{f}$ & $34.7 \mathrm{~g}$ \\
\hline & Caraway oil + No induced infection & $10.0 \mathrm{ij}$ & $12.0 \mathrm{kl}$ \\
\hline & Caraway oil + induced infection & $20.3 \mathrm{gh}$ & $24.0 \mathrm{i}$ \\
\hline \multirow[t]{2}{*}{ Temperature effect } & $0{ }^{\circ} \mathrm{C}$ & $36.9 \mathrm{~b}$ & $40.9 \mathrm{~b}$ \\
\hline & $25^{\circ} \mathrm{C}$ & $47.3 \mathrm{a}$ & $47.7 \mathrm{a}$ \\
\hline \multirow[t]{7}{*}{ Compound effect } & Control & $90.0 \mathrm{a}$ & $92.2 \mathrm{a}$ \\
\hline & $\mathrm{BTH}+\mathrm{No}$ induced infection & $63.2 \mathrm{c}$ & $62.8 \mathrm{c}$ \\
\hline & $\mathrm{BTH}+$ induced infection & $72.0 \mathrm{~b}$ & $72.5 \mathrm{~b}$ \\
\hline & Clove oil + No induced infection & $16.8 \mathrm{e}$ & $20.0 \mathrm{e}$ \\
\hline & Clove oil + induced infection & $28.5 \mathrm{~d}$ & $32.5 \mathrm{~d}$ \\
\hline & Caraway oil + No induced infection & $8.5 \mathrm{f}$ & $10.8 \mathrm{f}$ \\
\hline & Caraway oil + induced infection & $15.7 \mathrm{e}$ & $19.0 \mathrm{e}$ \\
\hline \multirow[t]{3}{*}{ LSD at $5 \%$} & Temperature $\times$ Compound & $5.8^{*}$ & $2.9^{*}$ \\
\hline & Temperature & $2.2 *$ & $1.1^{*}$ \\
\hline & Compound & $4.1^{*}$ & $2.0^{*}$ \\
\hline
\end{tabular}

Egypt. J. Hort. Vol. 42, No.1 (2015) 


\section{References}

Alma, M.H., Ertas, M., Nitz, S. and Kollmannsberger, H. (2007) Chemical composition and content of essential oil form the bud of cultivated Turkish clove (Syzygium aromaticum L.). BioResources, 2 (2), 265-269.

A.O.A.C. (1990) "Official Methods of Analysis", $15^{\text {th }}$ ed., The Association of Official Analytical Chemist, Virginia.

Ben-Chekroun, M., Amzile, J. and El-Yachioui, M. (1994) Qualitative and quantitative development of carbohydrate reserves during the biological cycle of Jerusalem artichoke (Helianthus tuberosus L.) tubers. New Zealand, J. Crop Hort. Sci., 22, 3137.

Bowler, C., Montogu, M.V. and Inze, D. (1992) Super oxide dismutase and stress tolerance. Ann. Rev. Plant Physiol. Plant Mol. Biol., 48, 233-250.

Cabezas M.J., Rabert, C., Bravo, S. and Shene, C. (2002) Inulin and sugar contents in Helianthus tuberosus and Cichorium intybus tubers: Effect of post harvest storage temperature. J. Food Science, 67, 2860-2865.

Chaieb, K., Hajlaoui, H., Zmantar, T., Kahla-Nakbi, A.B., Rouabhia, M. Mahdouani, K. and Bakhrouf, A. (2007) The chemical composition and biological activity of clove essential oil, Eugeniacaryophyllata (Syzygium aromaticum L.). Phytother. Res., 21, 501-506.

Charles, D.J. and Simon, J.E. (1990) Comparison of extraction methods for the rapid determination of essential oil content and composition of basil. J. Amer. Soc. Hort. Sci., 3, 458-462.

Chialva, F., Gabri, G., Plidde, P.A. and Ulian, F. (1982) Qualitative evaluation of aromatic herbs by direct head space (GC2) analysis of essential oils. pp. 183-195. In: M. A. Koedam and D. Vokou (Ed.). Matic Plants: Basic and Applied Aspects. Martinus Nishoff, the Netherlands.

Cieślik, E., Kopeć, A. and Praznik, W. (2005) Healthy properties of Jerusalem artichoke flour (Helianthus tuberosus L.). El. J. Polish Agric. Univ., Food Sci. Technol., 8/2/art-37.

Daniel, H.D. and George, C.M. (1972) Peach seed dormancy in relation to indogenous inhibitors and applied growth substances. J. Amer. Soc. Hort. Sci., 97, 651-654.

Daniels, L.B.J., Prange, R.K., Kalt, W., Liew., G.L., Walsh, J., Dean, P. and Coffin, R. (1996) The effects of ozone and 1, 8-cineole on sprouting, fry color and sugars of stored Russet Burbank potatoes. Amer. Potato J., 73, 469-481.

Danilčenko, H., Jarienė, E., Aleknavičienė, P. and Gajewski, M. (2008) Quality of Jerusalem artichoke (Helianthust uberosus L.) tubers in relation to storage conditions. Not. Bot. Hort. Agrobot. Cluj, 36 (2), 23-27. 
Davies, H. V. (1990) Carbohydrate metabolism during sprouting. Amer. Potato J., 67, 815-827.

Dubois, M., Gilles, K.A. Hamilton, J.K., Rebers, P.A. and Smith, F. (1956) Colorimetric method for determination of sugars and related substances. Anal. Chem., 28, 350-356.

El-Deeb, M.A.S., Mohamed, S.M., Elzahawy, A.M.H. and El-Gamal, E.A. (1993) Effect of nitrogen sources and levels on the growth, seed yield and oil content of Negillasativa L. Plant Egypt. J. Appl. Sci., 8(6), 387-409.

Frazier, M.J., Kleinkopf, E.G. and Olsen, N. (2006) Clove oil for potato sprout and silver scurf suppression in storage. Presented at the Idaho Potato Conference on January 19.

Hartmans, K. J., P. Diepenhorst, W. Bakker and L. G. M. Gorris (1995). The use of carvone in agriculture: Sprout suppression of potatoes and antifungal activity against potato tuber and other plant diseases. Indust. Crop Prod., 4, 3-13.

Jin, S., Liu, L. Liu, Z., Long, X., Shao, H. and Chen, J. (2013) Characterization of marine Pseudomonas spp. antagonist towards three tuber-rotting fungi from Jerusalem artichoke, a new industrial crop. Industrial Crops and Products, 43, 556-561.

Kays, S.J. and Nottingham, S.F. (2008) Biology and chemistry of Jerusalem artichoke (Helianthus tuberosusL.). CRC Press, Boca Raton, Florida. 459 p.

Miller, A.L. (1996) Antioxidant flavonoids: structure, function and clinical usage. Alt. Med. Rev., 1, 103.

Modler, H.W., Jones, J.D. and Mazza, G. (1993) Observations on long-term storage and processing of Jerusalem artichoke tubers (Helianthus tuberosus). Food Chem., 48, 279-284.

Oosterhaven, K., Hartmans, K.J. and Huizing, H.J. (1993) Inhibition of potato (Solanum tuberosum) sprout growth by the monoterpene s-carvone: reduction of 3hydroxy-3-methylglutaryl coenzyme A reductase activity without effect on its mRNA level. J. Plant Physiol., 141, 463-469.

Oosterhaven, K., K. J. Hartmans and J. J. C. Scheffer (1995) Inhibition of potato sprout growth by carvone enantiomers and their bioconversion in sprout. Potato Res., 38: $219-230$.

Pepeljnjak S., I. Kosalec, Z. Kalodera, and D. Kustrak (2003) Natural antimycotic from croatian plants. p. 49-79. In: Plant De-rived Antimycotics, Current Trends and Future Prospects (M. Rai, D. Mares, Eds.). Haworth press. Binghamtom, USA, 88p.

Robinson, R.G. (1973) Element composition and response to nitrogen of sunflower and corn. Agron. J., 66, 313.

Egypt. J. Hort. Vol. 42, No.1 (2015) 
Rojas, J.A., Dejaegher, F., Abdalla-Kotb, M. and Jardin, D.V. (2000) Expression and activity of antioxidant enzymes during potato tuber dormancy. Potato Res., 43, 383-393.

Saengthobpinit, W. and Sajjaanantakul, T. (2005) Influence of harvest time and storage temperature on charecteristics of inulin from Jerusalem artichoke (Helianthus tuberosus L.) tubers. Postharvest Biol. Technol., 37 (1), 93-100.

Schorr-Galindo, S. and Guiraud, J.P. (1997) Sugar potential of different Jerusalem artichoke cultivars according to harvest. Biores. Tech., 60, 15-20.

Snedecor, G.W. and W.G. Cochran (1982) "Statistical Methods", $7^{\text {th }}$ ed. $2^{\text {nd }}$ Printing, Iowa State. Univ. Press, Ame., USA, 507p.

Steel, R.G.D. and Torrie, J.H. (1980) " Principles and Procedures of Statistics. A Biometrical Approach ", $2^{\text {nd }}$ ed. McGraw-Hill Publishing Co., New York, USA.

Tesio, F., Weston, L.A. and Ferrero, A. (2011) Allelochemicals identified from Jerusalem artichoke (Helianthus tuberosus L.) residues and their potential inhibitory activity in the field and laboratory. Sci. Hort. Amsterdam, 129, 361-368.

Tournas, V.H. and Katsoudas, E. (2005) Mould and yeast flora in freshberries, grapes and citrus fruits. Int. J. Food Microbiol., 105, 11-17.

Velluti A., Sanchis, V., Ramos, A.J., Egido, J. and Marln, S. (2003) Inhibitory effect of cinnamon, clove, lemongrass, oregano and plamarose essential oils on growth and fumonisin B1 production by Fusrim proliferatum in maize grain. J. Food Microbil., 89, 145-154.

Wang, Y.F., Tang, F., Xia, J.D., Yu, T., Wang, J., Azhati, R. and Zheng, X.D. (2011) A combination of marine yeast and food additive enhances preventive effects on postharvest decay of jujubes (Zizyphus jujuba). Food Chem., 125, 835-840.

Winton, A.L. and Winton, K.B. (1958) " The Analysis of Foods ", John Wiley \& Sons. Inc. Londan, 857p.

Yamazaki, I. and Biette, L.H. (1963) Biochim. Biophys. Acta, 77, 47-64.

(Received 7/10/2014; accepted $9 / 2$ /2015) 


\section{تحسين الجودة والقدرة التخزينية ومقاومة أعفان درنات الطرطوفة باستخدام الزيوت العطرية ودرجات الحرارة}

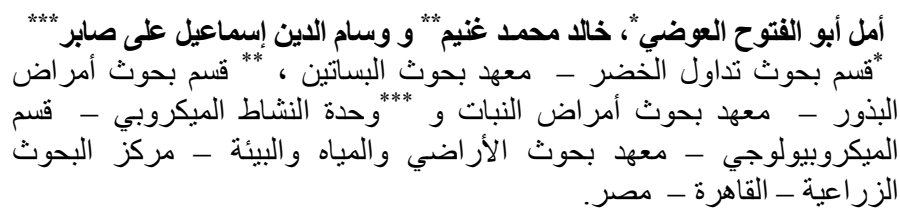

أجريت تجربتان تخزينيتان بمحطة بحوث البساتين بالمنصورة- معهد بحوث إثراث

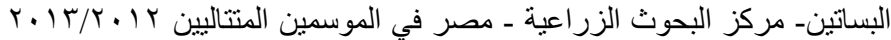

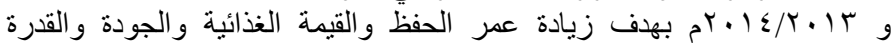

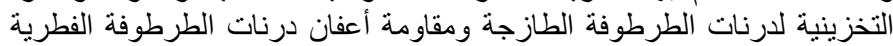

$$
\text { تحت ظروف التخزين. }
$$

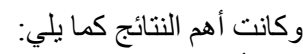

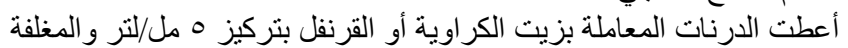

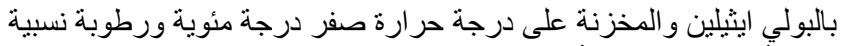

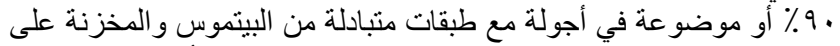

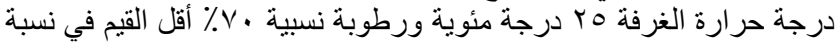

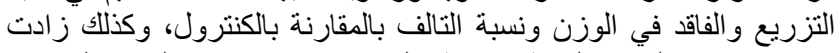

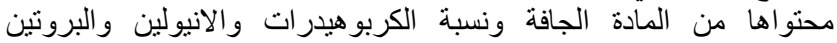

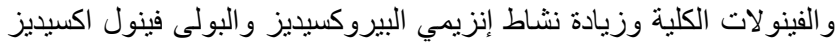
في موسمي الدراسة.

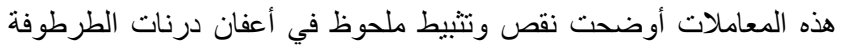
تحت ظروف العدوى الصناعية وظروف التخزين و المقارنة بالمادة الكيميائية.

توصي هذه الدراسة بتخزين درنات الطرطوفة على درجة حرارة الغرفة الغرة

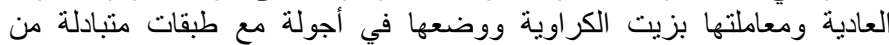

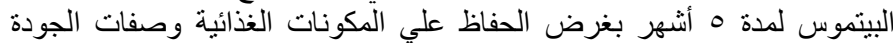

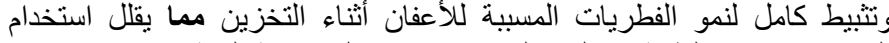
المبيدات وترشيد الطاقة وتكاليف التخزين علاوة على حماية البيئة. 